\title{
アンモニア処理活性炭による銅（II）イオンの吸着
}

\author{
岡山 玲子'1), Muhammad Abbas AHMAD ZAINI ${ }^{1)}$, 相川 正美2), \\ 町田 基 ${ }^{1,3)}$, 立本 英機1,3) \\ 1) 千葉大学大学院工学研究科（豆263-8522 千葉県千葉市稲毛区弥生町 1-33） \\ ${ }^{2}$ 木更津工業高等専門学校（干290-0041 千葉県木更津市清見台東2-11-1） \\ 3)千葉大学総合安全衛生管理機構（广 263-8522 千葉県千葉市稲毛区弥生町1-33）
}

[平成20年 6 月 24 日受付，平成20年10月29日受理］

\section{Adsorption of copper(II) ions onto activated carbons treated by ammonia gas}

\author{
Reiko OKAYAMA ${ }^{1)}$, Muhammad Abbas AHMAD ZAINI ${ }^{1)}$, Masami AIKAWA ${ }^{2)}$, \\ Motoi MACHIDA $^{1,3)}$ and Hideki TATSUMOTO ${ }^{1,3)}$ \\ ${ }^{1)}$ Graduate School of Engineering, Chiba University \\ (1-33 Yayoi, Inage, Chiba, Chiba 263-8522) \\ ${ }^{2)}$ Faculty of Science, Kisarazu College of Technology \\ (2-11-1 Kiyomidai-higashi, Kisarazu, Chiba 292-0041) \\ ${ }^{3}$ Safety and Health Organization, Chiba University \\ (1-33 Yayoi, Inage, Chiba, Chiba 263-8522)
}

[Received June 24, 2008; Accepted October 29, 2008]

\begin{abstract}
Summary
Activated carbon (AC) was treated by ammonia gas to introduce nitrogen element on the graphite sheets for enhancing adsorption amount of copper(II) ions in aqueous solution. The nitrogen content was increased with the rise in $\mathrm{NH}_{3}$ treatment temperature. Though any significant textural properties was not observed in the $\mathrm{NH}_{3}$ treatment up to $700{ }^{\circ} \mathrm{C}$, BET and meso-pore specific surface areas were increased above $800{ }^{\circ} \mathrm{C}$ indicating that the $\mathrm{NH}_{3}$ etched and gasified carbons to produce $\mathrm{CH}_{4}$. $\mathrm{AC}$ was also out-gassed in $\mathrm{He}$ flow at $1000{ }^{\circ} \mathrm{C}$ to remove surface acidic oxygen for the comparison with the $\mathrm{NH}_{3}$ treatment. Successfully applying the Langmuir adsorption isotherms to the experimental results, the adsorption capacity of copper(II) ions onto the $\mathrm{NH}_{3}$ treated $\mathrm{AC}$ at $700{ }^{\circ} \mathrm{C}(7 \mathrm{AG})$ was greater than the outgassed carbon (OG). The amount of copper(II) ions desorption from 7AG was smaller than that from OG. In contrast, adsorption amount of proton on 7AG was smaller than that of OG from the $\mathrm{pH}$ alternation, suggesting that $\pi$-electrons on the graphene layers might be withdrawn by nitrogen introduced, then $\pi$-electrons density would be decreased. Some amount of copper(II) ions adsorption onto 7AG could be observed even if the $\mathrm{pH}$ was less than 3 , whereas it was hardly taken place for OG. Based on the experimental results, the introduced nitrogen atoms are estimated to become new strong adsorption sites for the copper(II) ions adsorption, probably transferring loan pair electrons of nitrogen on the graphite sheets to the copper(II) ions.
\end{abstract}

Key words: activated carbons, ammonia treatments, copper ions, surface nitrogen, adsorption capacity 


\section{1. はじめに}

工業, 産業の発展と共に様々な環境問題への関心が高 まっている。その中でも工業排水, 生活排水等による湖 沼や河川の污染は我々に身近な環境問題として重要な問 題のひとつである。工場以外に鉱山や産業廃棄物からの 流出も起こりうる重金属イオンは, 生分解性がないため 有毒性が持続し，土壤污染や食物污染などをもたらす1)。 銅イオンは生物にとって必須元素のひとつであるが, 足 尾銅山鉱毒事件で知られるように，魚類や穀物に悪影響 を及ぼし,さらには過剩に㠌取すると人体に肝障害を及 ぼしうる。有害物質に対しては排水基準㧍よび水道水基 準が定められており, 銅イオンはそれぞれ $3 \mathrm{mg} / \ell^{2)}$, 1. $0 \mathrm{mg} / \ell^{3)}$ である。

工業廃水の処理方法として, 沈殿法, イオン交換法, 吸着法などがあるが, 中でも活性炭による吸着方法は久 ラッジの発生がなく, 吸着後に脱離させることで活性炭 の再利用が可能であるため, 広く利用されている ${ }^{4)}$ 。活 性炭による吸着は有機物に対して特に有効であるが, 重 金属イオンの吸着に関する研究もなされている5,6)。

既往の研究により, 酸性官能基を含まない活性炭（脱 気活性炭）は有機物の吸着に有効であり, 酸性官能基を 豊富に含む活性炭（酸化活性炭）は重金属イオンの吸着 に有効であることが分かっている5)。重金属イオンは脱 気活性炭へ $\pi$-カチオン相互作用により吸着, さらに酸 化活性炭へはイオン交換により吸着することがわかって いる ${ }^{5.77}$ 。

また，窒素含有塩基性官能基の影響に関する研究も多 く行われている。例えば, Koh $ら^{8)}$ は, 窒素が活性炭表面 に導入されることによって $\pi$ 電子密度が低下し, 有機物 との $\pi-\pi$ 相互作用が弱まって有機物吸着に不利になる と報告している。一方 Przepiorski" は窒素官能基により 活性炭が塩基性になり, 弱酸性であるフェノールの吸着 量が増大したと報告している。Dastgheib ${ }^{10}$ は $\mathrm{NH}_{3}$ 処理 により活性炭表面がエッチングされ高表面積になるの で, 窒素含有量にかかわらず接触表面積の高いことが理 由で DOM 吸着量が増加したと報告している。Mangun $ら^{111}$ は, $\mathrm{HCl}$ ガス吸着量は窒素の化学状態に関係なく窒 素含有量に比例すると報告している。

このように窒素含有活性炭による吸着実験は多数行わ れているが，吸着機構に関して解釈の異なる報告が多 く, また, 脱気活性炭や酸化活性炭との比較や重金属人 オン吸着に対する影響についての研究は少ない。そこ で, 本研究では活性炭を $\mathrm{NH}_{3}$ ガスで処理することにより 塩基性窒素を導入し, 重金属イオンである $\mathrm{Cu}$ (II) イオ ンを吸着質として用い, 脱気活性炭と比較して窒素含有 塩基性官能基が吸着性能に及ぼす影響とその吸着メカニ ズムについて検討した。

\section{2. 実験方法}

\section{1 活性炭の調整}

\section{1 . 1 脱灰処理}

石炭系粒状活性炭 Filtrasorb400（三菱化学カルゴン 製，F400）を0.5〜2 mmにそろえた後， $\mathrm{pH}$ が安定する まで蒸留水で煮沸洗浄した。その後 $2 \mathrm{M}$ の $\mathrm{HCl}$ を $300 \mathrm{~m} \ell$ 加え $6 \mathrm{~h}$ 静置し, $\mathrm{HCl}$ を替えて再び $6 \mathrm{~h}$ 静置した。続いて $46 \% \mathrm{H}_{2} \mathrm{~F}_{2}$ 中で一晚置いた後 $\mathrm{H}_{2} \mathrm{~F}_{2}$ を替えて 3 h 静置した。 $\mathrm{pH}$ が一定になるまで蒸留水で煮沸洗浄した。これを $110^{\circ} \mathrm{C}$ で乾燥させたものを DA（De-Ashed-F400）とした。

\section{1.2 脱気処理}

$110^{\circ} \mathrm{C}$ で $1 \mathrm{~h}$ 乾燥させた DA $6 \mathrm{~g}$ を石英管（直径 $22 \mathrm{~mm}$, 長さ $600 \mathrm{~mm}$ ）に入れ, $150 \mathrm{~m} \ell / \mathrm{min}$ の $\mathrm{He}$ 気流中で $1,000^{\circ} \mathrm{C}$ まで昇温させ, $1,000^{\circ} \mathrm{C} て ゙ 1 \mathrm{~h}$ 保持した。その後 $\mathrm{He}$ 気流 中で室温まで放冷した。これを OG（Out-Gassed-DA）と した。

\section{1.3 酸化処理}

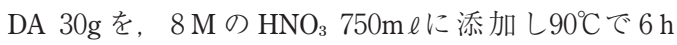
加熱した。その後 $\mathrm{pH}$ が一定となるまで蒸留水で煮沸洗

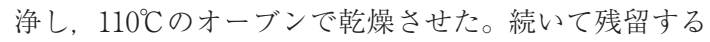
$\mathrm{NO}_{3}{ }^{-}$を除去するため $350^{\circ} \mathrm{C}$ のマッフル炉で $4 \mathrm{~h}$ 焼成した。 これを Ox (Oxidized-DA) とした。

\section{1. $4 \mathrm{NH}_{3}$ 処理}

$110^{\circ} \mathrm{C}$ で $1 \mathrm{~h}$ 乾燥させた DA $6 \mathrm{~g}$ を脱気処理と同様の石 英管に入れ，所定の温度 $\left(500,700,800,900^{\circ} \mathrm{C}\right)$ まで $150 \mathrm{~m} \ell / \min$ の $\mathrm{He}$ 気流中で昇温した。所定温度に達した 後 $\mathrm{NH}_{3}$ に切り替え, $250 \mathrm{~m} \ell / \min の \mathrm{NH}_{3}$ 気流中で $1 \mathrm{~h}$ 処理 した。 $\mathrm{NH}_{3}$ 気流中で $500^{\circ} \mathrm{C}$ まで降温させ，ガスを $\mathrm{He} に$ に切 り替えて $500^{\circ} \mathrm{C} て ゙ 0.5 \mathrm{~h} \mathrm{NH}_{3}$ 脱離した後, $\mathrm{He}$ 気流中で室温 まで放冷した。これを $\mathrm{xAG}\left(\mathrm{x} 00^{\circ} \mathrm{C}\right.$ Ammonia Gas Treated-DA）とした。

$\mathrm{Xia} ら^{12}$ により, カーボンナノチューブに吸着した $\mathrm{NH}_{3}$ は昇温脱離に扔いて $120 \sim 500^{\circ} \mathrm{C}$ で完全に脱離すると報告 されている。この報告に従い, $\mathrm{NH}_{3}$ 処理後に $500^{\circ} \mathrm{C} て ゙ の$ 脱 気を行った。

\section{2 吸着剤物性の測定}

\section{2. 1 BET 比表面積 - 細孔分布測定}

吸着剤 $0.07 \mathrm{~g}$ を $110^{\circ} \mathrm{C}$ のオーブンで $1 \mathrm{~h}$ 乾燥させた後,


後液体窒素温度 $\left(-196^{\circ} \mathrm{C}\right)$ に扔ける $\mathrm{N}_{2}$ 吸脱着測定から BET 比表面積を得た。また, $t$-プロット法によりマイク 口孔 $(<2 \mathrm{~nm})$ 表面積を得た ${ }^{13)}$ 。

\section{2 . 2 元素分析}

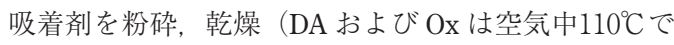
$1 \mathrm{~h}, \mathrm{OG}$ 抢よびxAG は $\mathrm{He}$ 気流中 $200^{\circ} \mathrm{C} て ゙ 1 \mathrm{~h} ） し ， 1 \mathrm{mg}$ をスズ箔に包み $980^{\circ} \mathrm{C} て ゙$ 完全燃焼した。燃燒によって生 
じた $\mathrm{CO}_{2}, \mathrm{H}_{2} \mathrm{O}$ ，および $\mathrm{NOx}$ を還元して得られる $\mathrm{N}_{2}$ を定 量することにより，C， H， N の含有率を求めた。また， 吸着剤の組成を C, H, N , O のみと仮定し，100\%から $\mathrm{C}, \mathrm{H}, \mathrm{N}$ 含有率を差し引くことにより $\mathrm{O}$ 含有率を算出し た。

\section{2. $3 \mathrm{Cu}$ (II) イオンの吸着実験}

\section{3. 1 吸着}

初濃度を調整した $\mathrm{CuCl}_{2}$ 水溶液 $25 \mathrm{~m} \ell$ に 2 種の活性炭 （OG，7AG）50mgをそれぞれ添加し $25^{\circ} \mathrm{C} ， 100 \mathrm{rpm}$ で吸 着平衡に達するまで 2 日間振とうさせた。原子吸光光度 計（アナリティクイエナ, novAA300）を用いて濃度を測 定し，平衡吸着量を算出した。また吸着前後の $\mathrm{pH}$ （初 期 $\mathrm{pH}$ 及び平衡 $\mathrm{pH}$ )を $\mathrm{pH}$ メーター（堀場製作所， D-21） で測定した。

さらに, 平衡濃度 $C_{e}[\mathrm{mmol} / \ell]$ 㧍よび平衡吸着量 $Q_{e}$ $[\mathrm{mmol} / \mathrm{g}]$ を以下のラングミュア式に当てはめ, 最大吸 着容量 $X_{m}[\mathrm{mmol} / \mathrm{g}]$ 抢よび吸着親和力 $K_{e}[\ell / \mathrm{mmol}]$ を算出 した。

ラングミュア式

$$
\frac{C_{e}}{Q_{e}}=\frac{1}{X_{n}} C_{e}+\frac{1}{X_{m} K_{e}}
$$

\section{3. 2 脱着}

2. 3. 1で吸着平衡に達した後, 溶液をデカンテー ションにより除去し, 蒸留水 $25 \mathrm{~m} \ell$ を加えて $100 \mathrm{rpm}$ で 2 日間振とうさせ，平衡濃度を測定し，脱着量を算出し た。

\section{3. 3 吸着の $\mathrm{pH}$ 依存性}

0.1 または $1 \mathrm{M} の \mathrm{HCl}$ 用いて初期 $\mathrm{pH} 2 \sim 6$ に調整 した初濃度 $0.8 \mathrm{mmol} / \ell$ の $\mathrm{CuCl}_{2}$ 水溶液について2. 3. 1 吸 着と同様の方法で吸着剤 OG および7AG について吸着実 験を行った。なお， pH6.3以上では $\mathrm{Cu}(\mathrm{OH})_{2}$ の沈殿が生 じてしまうため, $\mathrm{pH}$ はそれ以下に調整した。

\section{3. 結果および考察}

\section{1 吸着剤の物性}

\section{1. 1 BET 比表面積および細孔構造}

DA，OG，Ox，5-9AGs の重量減少，BET 比表面積㧍 よび細孔分布を Table 1 に示す。

$700^{\circ} \mathrm{C}$ 以下に抏いて $\mathrm{NH}_{3}$ 処理をしても，重量減少およ び表面構造の変化はほとんどなかった。一方， $800^{\circ} \mathrm{C}$ 以 上での $\mathrm{NH}_{3}$ 処理により, 重量は $20 \%$ 近く減少し, メソ・ マクロ孔比表面積は 2 倍以上に, 総比表面積は約1.3倍 に増加した。 $\mathrm{NH}_{3}$ のエッチング作用により炭素がガス化 しメソ・マクロ孔が生成し, 総表面積が増加したのだと

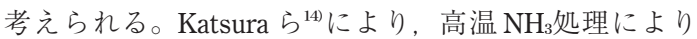
$\mathrm{CH}_{4}$ が生成するという報告がなされている。
$3 \mathrm{C}+4 \mathrm{NH}_{3} \rightarrow 3 \mathrm{CH}_{4} \uparrow+2 \mathrm{~N}_{2} \uparrow$

また，活性炭表面上の酸性官能基と $\mathrm{NH}_{3}$ の反応で生じ た水によっても炭素がガス化したと考えられる。安部ら 15)によると水蒸気による $\mathrm{C}$ のガス化は $750^{\circ} \mathrm{C}$ 以上で起こ るとされている。

$$
\begin{aligned}
& -\mathrm{COOH}+\mathrm{NH}_{3} \rightarrow-\mathrm{CONH}_{2}+\mathrm{H}_{2} \mathrm{O} \\
& \mathrm{C}+\mathrm{H}_{2} \mathrm{O} \rightarrow \mathrm{CO} \uparrow+\mathrm{H}_{2} \uparrow
\end{aligned}
$$

\section{1.2 元素組成}

元素分析によって得られた $\mathrm{C}, \mathrm{H}, \mathrm{N}$ ，および $\mathrm{O}$ の組成 含有率を Table 2 に示す。

5-9 AGs すべてにおいて O 含有率は減少し，N 含有 率は増加している。これは活性炭表面に存在する酸性官 能基が $\mathrm{NH}_{3}$ によって還元されて活性炭表面上にシアノ基 等が生成したためと考えられる。シアノ基の生成は Chen W. ら ${ }^{16)}$ にも報告されている。

$$
-\mathrm{COOH}+\mathrm{NH}_{3} \rightarrow-\mathrm{COO}^{-} \mathrm{NH}_{4}{ }^{+} \rightarrow-\mathrm{CONH}_{2} \rightarrow-\mathrm{C} \equiv \mathrm{N}
$$

また, $800^{\circ} \mathrm{C}$ 以上の $\mathrm{NH}_{3}$ 処理活性炭では $\mathrm{O}$ 含有率と共 にC 含有率も減少している。 $\mathrm{NH}_{3}$ の窒素原子が活性炭の 炭素骨格に導入し，ピリジン類が生成したためと考えら れる。これは Mangun $ら^{111}$ の報告と一致している。

表面積, 細孔分布といった構造および元素組成の測定 結果より, 含有窒素のみによる影響を検討するため, $\mathrm{OG}$ 扔よび OG と構造が同様で窒素含有率が約7.1倍であ る7AGの 2 種の活性炭を用いて $\mathrm{Cu}$ （II）イオン吸着実 験を行った。なお，8AG 㧍よび9AG は高い窒素含有率で あったが構造が対照吸着剤である OG とは異なったた め, 吸着実験には用いなかった。

\section{3. $2 \mathrm{Cu}(\mathbb{I I})$ イオンの吸脱着}

\section{2.1 吸着}

$\mathrm{Cu}$ （II）イオン吸着等温線を Fig. 1 に示す。また，ラ ングミュア等温式に当てはめ描いたラングミュア等温線 をFig. 2 に，それより算出した最大吸着容量抒よび吸着 親和力を Table 3 に示す。最大吸着容量は7AGが OG の約 1. 5 倍高く, 吸着親和力は OG のほうが若干高い值で あった。

$\mathrm{Cu}$ （II）イオン平衡濃度と平衡 $\mathrm{pH}$ の関係を Fig. 3 に 示す。 $\mathrm{OG}$ より7 $\mathrm{AG}$ の平衡 $\mathrm{pH}$ は低い。OG のほうが $\mathrm{H}^{+}$ を吸着しやすいということである。 $\mathrm{NH}_{3}$ 処理で窒素が活 性炭に導入されたことにより表面の窒素周辺の $\pi$ 電子雲 密度が低下し，そのため $\pi$ 電子雲への $\mathrm{H}^{+}$及び $\mathrm{Cu}$ （II） イオン吸着量は減少したと考える。7AGに抒いて $\pi$ 電 子密度が低下したにもかかわらず $\mathrm{Cu}$ （II）イオン吸着 量が増加したのは， $\pi$ 電子雲とは異なる新たな吸着点と 
Table 1 Properties of the carbon adsorbents

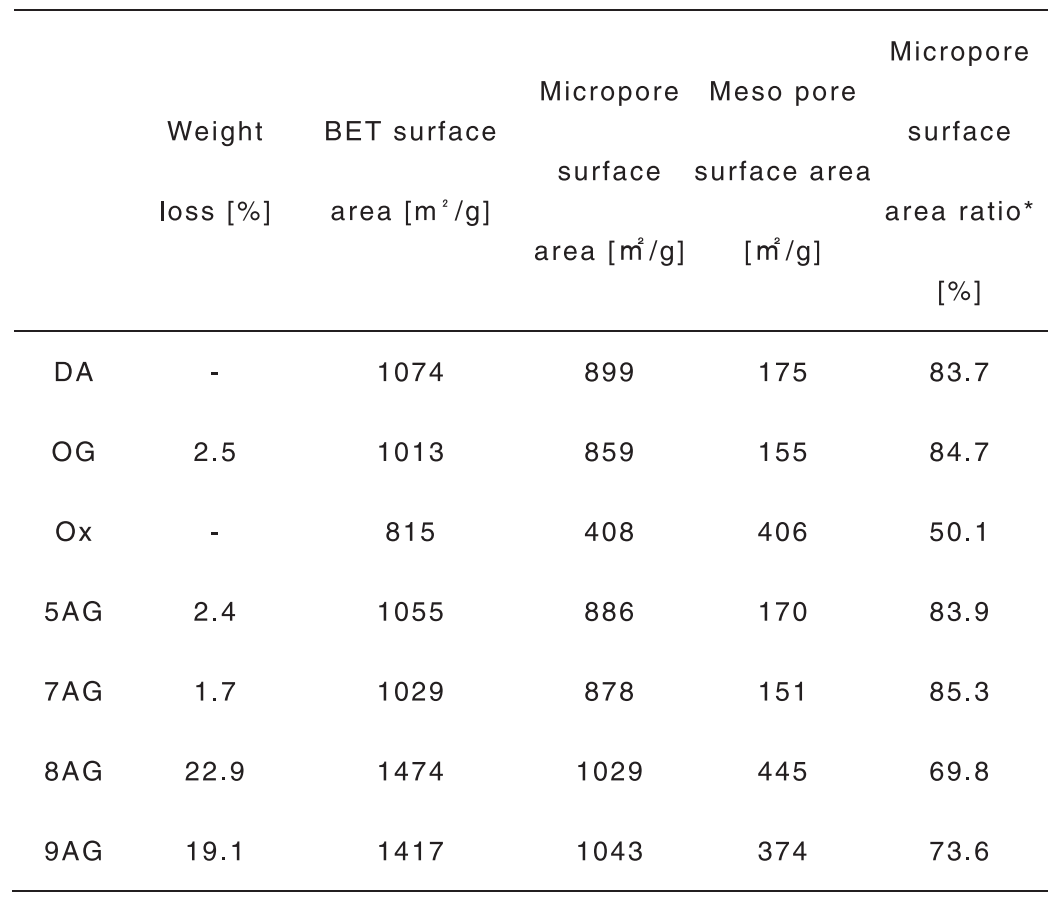

* micropore surface area ratio = micropore surface area $/$ BET surface area $\times 100$

DA : De-Ashed activated carbon, OG: Out-Gassed DA, Ox: Oxidized DA, 5-9AG: Ammonia Gas treatmented DA at 500-900 $\mathrm{C}$

Table 2 Elemental compositions of the carbon adsorbents

\begin{tabular}{ccccc}
\hline & $C[w \%]$ & $H[w \%]$ & $N[w \%]$ & $O^{*}[w \%]$ \\
\hline DA & 93.4 & 0.03 & 0.37 & 6.21 \\
OG & 96.0 & 0.00 & 0.39 & 3.59 \\
Ox & 82.6 & 0.07 & 1.05 & 16.3 \\
$5 \mathrm{AG}$ & 94.7 & 0.06 & 0.86 & 4.37 \\
$7 \mathrm{AG}$ & 93.1 & 0.01 & 2.76 & 4.16 \\
$8 \mathrm{AG}$ & 91.7 & 0.01 & 3.60 & 4.69 \\
$9 \mathrm{AG}$ & 92.4 & 0.00 & 3.38 & 4.26 \\
\hline
\end{tabular}

*balance 


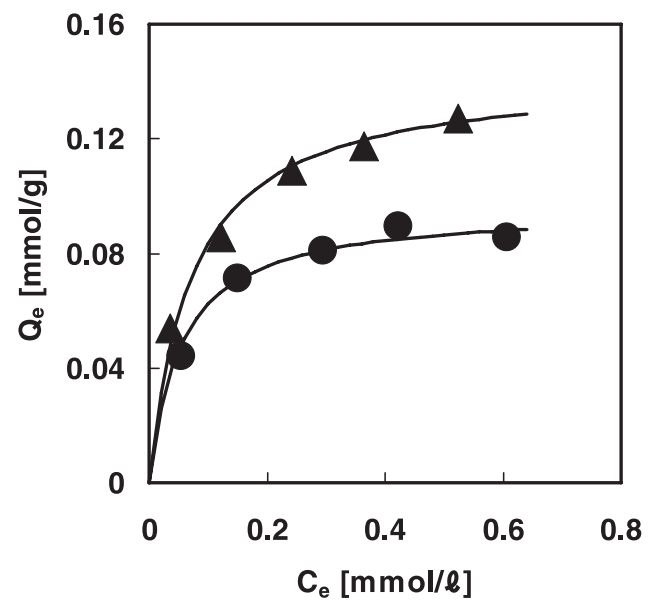

Fig. 1 Adsorption isotherms of $\mathrm{Cu}$ (II) ions onto out-gassed (OG) and $700{ }^{\circ} \mathrm{C}$ ammonia gas treated $(7 \mathrm{AG})$ activated carbon

; $\mathrm{OG}, \boldsymbol{\Delta} ; 7 \mathrm{AG}$

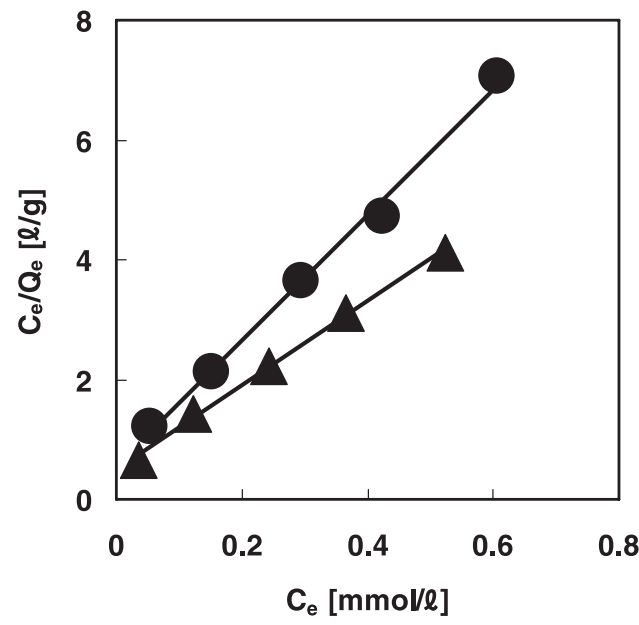

Fig. 2 Langmuir plots of adsorption isotherms for $\mathrm{Cu}(\mathrm{II})$ ions adsorption onto out-gassed (OG) and $700{ }^{\circ} \mathrm{C}$ ammonia gas treated (7AG) activated carbons

; $\mathrm{OG}, \boldsymbol{\Delta}$; $7 \mathrm{AG}$

Table 3 Langmuir parameters of $\mathrm{Cu}(\mathrm{II})$ ions adsorption

\begin{tabular}{cccc}
\hline & $X_{m}[\mathrm{mmol} / \mathrm{g}]$ & $K_{e}[\mathrm{l} / \mathrm{mmol}]$ & $R^{2}$ \\
\hline OG & 0.0958 & 18.6 & 0.9951 \\
7AG & 0.143 & 14.0 & 0.9977 \\
\hline
\end{tabular}

$X_{m}$ : maximum adsorption capacity, $K_{e}$ : adsorption affinity

なった窒素原子へ $\mathrm{Cu}$ （II）イオンが選択的に吸着した ためと考えられる。

\section{2. 2 脱着}

$\mathrm{Cu}$ （II）イオンの初濃度と吸脱着量の関係を Fig. 4 に 示す。7AGの吸着量は $\mathrm{OG} よ り$ 高いにもかかわらず脱着 量は低い。7AGの吸着点として考えられるのは $\pi$ 電子 雲と窒素であるが, $\mathrm{OG}$ の脱着結果から， $\pi$ 電子雲に吸 着した $\mathrm{Cu}$ （II）イオンは脱着すると分かっているので, 7AGにおいて脱着した $\mathrm{Cu}$ (II）イオンをすべて $\pi$ 電子 雲へ吸着したものと仮定する。脱着量が OGよりも低下 している原因として，3．2．1で述べたように活性炭表 面の $\pi$ 電子密度が低下し， $\pi$ 電子雲への $\mathrm{Cu}(I I)$ イオン 吸着量が減少したためと考えられる。7AGから脱着し た $\mathrm{Cu}$ (II）イオンはすべて $\pi$ 電子雲に吸着したものと 仮定したが,これはつまり窒素に吸着した $\mathrm{Cu}$ (II) イオ ンは脱着が困難であるということである。これは $\mathrm{Cu}$ (II) イオンの $\pi$ 電子雲との相互作用よりも窒素との 相互作用のほうが強いためと考えられる。窒素原子のも つ非共有電子対に $\mathrm{Cu}$ （II）イオンが電荷移動錯体をつ くり吸着したと考えられる。これは $\pi$ 電子雲との相互作
用より強いため, 脱着しにくく, さらに吸着親和力は高 くなると推測できる。しかし Table 3 より, OG の吸着親 和力のほうが高かった。 $\mathrm{Cu}$ (II) イオンは水溶液中で式 （6）の平衡状態で存在し, $\mathrm{pH}$ を上昇させると $\mathrm{pH} 6.3$ 付 近で $\mathrm{Cu}(\mathrm{OH})_{2}$ が生じ始めるため, $\mathrm{pH} 6$ 付近では $\mathrm{Cu}(\mathrm{OH})^{+}$ が多く存在していると考えられる。

$$
\mathrm{Cu}^{2+}+2 \mathrm{H}_{2} \mathrm{O} \rightleftarrows \mathrm{Cu}(\mathrm{OH})^{+}+\mathrm{H}^{+}+\mathrm{H}_{2} \mathrm{O} \rightleftarrows \mathrm{Cu}(\mathrm{OH})_{2}+\mathrm{H}^{+}
$$

$\mathrm{Cu}^{2+}$ の水和水に比べ $\mathrm{Cu}(\mathrm{OH})^{+}$のそれは分解されやす く $\mathrm{Cu}(\mathrm{OH})^{+}$のほうが吸着しやすいと考えると, 平衡 $\mathrm{pH}$ が高く $\mathrm{Cu}(\mathrm{OH})^{+}$の存在率の高い $\mathrm{OG}$ のほうが $\mathrm{Cu}$ (II) イオン吸着に有利である。そのため OGによる吸着が有 利となり吸着親和力に差が出たと推測できる。

\section{2 . 3 吸着の $\mathrm{pH}$ 依存性}

初濃度を $0.8 \mathrm{mmol} / \ell$ と一定とし初期 $\mathrm{pH}$ を $2-6$ に調整 したときの吸着実験における平衡 $\mathrm{pH}$ と平衡吸着量の関 係を Fig. 5 に示す。OG では pH5. 5以下ではほとんど吸 着しない。これは, 低 $\mathrm{pH}$ では $\mathrm{H}^{+}$濃度が高いので $\mathrm{Cu}^{2+}$ と $\mathrm{H}^{+}$との競争吸着により, 表面被覆率において $\mathrm{H}^{+}$吸着が 


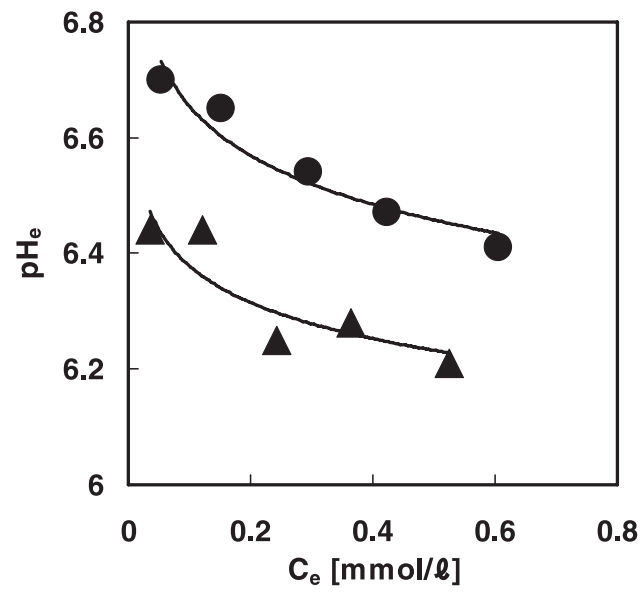

Fig. 3 Relationship between equilibrium $\mathrm{Cu}$ (II) ions concentration and equilibrium $\mathrm{pH}$ when $\mathrm{Cu}(\mathrm{II})$ ions were adsorbed onto outgassed (OG) and $700{ }^{\circ} \mathrm{C}$ ammonia gas treated (7AG) activated carbons

; $\mathrm{OG}, \boldsymbol{\Delta} ; 7 \mathrm{AG}$



Fig. 4 Adsorption and desorption amounts of $\mathrm{Cu}(\mathrm{II})$ ions onto out-gassed (OG) and $700^{\circ} \mathrm{C}$ ammonia gas treated (7AG) activated carbons against initial $\mathrm{Cu}(\mathrm{II})$ ions concentration

; adsorption to $\mathrm{OG}, \mathbf{\Delta}$; adsorp-tion to $7 \mathrm{AG}$, $\bigcirc$; desorption from $\mathrm{OG}, \triangle$; desorption from $7 \mathrm{AG}$ after adsorption equilibrium is attained with the corre-sponding initial concentration for the adsorption



Fig. 5 Changes in adsorption amounts of $\mathrm{Cu}$ (II) ions onto out-gassed (OG) and $700{ }^{\circ} \mathrm{C}$ ammonia gas treated (7AG) activated carbons as a function of equilibrium solution $\mathrm{pH}\left(\mathrm{pH}_{\mathbf{e}}\right)$

; $\mathrm{OG}, \boldsymbol{\Delta} ; 7 \mathrm{AG}$

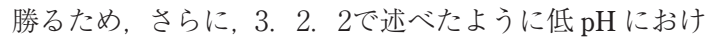
る $\mathrm{Cu}$ (II) イオンの化学種が $\mathrm{Cu}^{2+}$ でありこれは高 $\mathrm{pH} に$ 拉いて存在する化学種 $\mathrm{Cu}(\mathrm{OH})^{+}$よりも吸着しにくいた めと考える。しかし7AG では低 $\mathrm{pH}$ からの吸着が可能で あった。3．2．1に述べたように表面に導入された窒素 は $\mathrm{H}^{+}$よりも $\mathrm{Cu}$ (II) イオンを選択的に吸着するためと

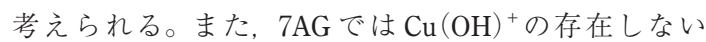
pH5. 5 以下に扔いても吸着が観測されたことから, $\mathrm{Cu}(\mathrm{OH})^{+}$以外に $\mathrm{Cu}^{2+}$ の吸着も可能になったと推測できる。

\section{4. 結論}

$\mathrm{NH}_{3}$ で処理することにより窒素原子を導入させた活性 炭を作成した結果，以下のことが明らかになった。

1. $\mathrm{NH}_{3}$ 処理により窒素含有率が増加し, $800^{\circ} \mathrm{C}$ 以上の $\mathrm{NH}_{3}$ 処理ではエッチング作用によって BET 比表面積, メソ・マクロ孔表面積も増加した。

2 . 窒素の導入により活性炭表面上の $\pi$ 電子密度が低下 し, $\mathrm{H}^{+}$吸着量が減少した。

3. $\mathrm{H}^{+}$は $\pi$ 電子雲への吸着選択性は高いが窒素には吸 着しにくい。

4. 活性炭表面上の窒素は $\mathrm{Cu}$ （II）イオンを選択的に吸 着し $\mathrm{H}^{+}$の影響を受けにくいため $\mathrm{NH}_{3}$ 処理活性炭によ る $\mathrm{Cu}$ (II) イオン吸着量は増加した。

5. 窒素と $\mathrm{Cu}$ （II）イオンの吸着は電荷移動相互作用に よる吸着であると考えられ, 強い相互作用であるため $\pi$ 電子雲との相互作用に比べて脱着が困難である。

6. 窒素原子の導入により低 $\mathrm{pH}$ の水溶液からの $\mathrm{Cu}$ 
（II）イオン吸着が可能となった。

\section{謝 辞}

本稿で紹介した研究の一部は, 日本学術振興会・科学 技術研究費補助金・基盤研究 C「炭素の表面科学と水質 污染物質の吸着・分解メカニズムの解明 (No.20510072)」の助成を受けたものである。また，本 研究を進めるにあたり，多岐にわたるご援助をいただき ました千葉大学総合衛生管理機構の長尾啓一機構長（教 授, 医学博士）に厚く御礼申し上げます。

\section{要 約}

石炭系活性炭を $1,000^{\circ} \mathrm{C}$ で $\mathrm{He}$ 処理（OG）または500〜 $900^{\circ} \mathrm{C}$ で $\mathrm{NH}_{3}$ 処理（5-9AG）した。AGsにおいて, 処理温 度の上昇に伴い窒素含有率は増加し, $800^{\circ} \mathrm{C}$ 以上では表 面積も増加した。OG および7AG を用いた水溶液中の $\mathrm{Cu}$ (II) イオンの吸着実験の結果, 7AGのほうが $\mathrm{Cu}$ （II）イオン吸着量が大きく, $\mathrm{H}^{+}$吸着量が小さかっ た。また, 7AGでは低 $\mathrm{pH} て ゙ の \mathrm{Cu}$ (II）イオン吸着が可能 であった。窒素の導入により $\pi$ 電子密度が低下し, さら に $\mathrm{Cu}$ （II）イオンの吸着選択性が発生したと考えられ る。また，7AGの Cu（II）イオン脱着量が低いことか ら, 窒素への $\mathrm{Cu}$ (II）イオン吸着親和性は大きいと推測 できる。

\section{文 献}

1）浅見輝男, 本間 慎, 田辺晃生, 畑 明郎：生野鉱 山などから排出されたカドミウム, 亜鉛, 鉛, 銅に よる市川・円山川底質の污染, 日本土壤肥料学雑 誌，52-5，433-438（1981）

2）環境省：水質污濁防止法排水基準を定める省令 (2006)

3）厚生労働省：水道法水質基準に関する省令（2001）

4）石原 篤：活性炭吸着, pp30-31, 「絵とき下水・污 泥処理の基礎」, 夕クマ環境技術研究会編集, 株式 会社オーム社, 東京 (2005)

5) Sato, S., Yoshihara, K., Moriyama, K., Machida, M. and Tatsumoto, H.: Influence of activated carbon surface acidity on adsorption of heavy metal ions and aromatics from aqueous solution. Applied Surface Science, 253, 8554-8559 (2007)

6) Amuda, O.S., Giwa, A.A. and Bello, I.A.: Removal of heavy metal from industrial wastewater using modified activated coconut shell carbon. Biochemical Engineering Journal, 36, 174-181 (2007)

7）吉原和矢, 町田 基, 相川正美, 藤村葉子, 立本英 機: 活性炭の酸性官能基の有無がカドミウムイオン の吸着・脱着挙動に及ぼす影響, 環境化学, 174, 635-641 (2007)

8) Koh, M. and Nakajima, T.: Adsorption of aromatic compounds on $\mathrm{CxN}$-coated activated carbon. Carbon, 38, 1947-1954 (2000)

9) Przepiorski, J.: Enhanced adsorption of phenol from water by ammonia-treated activated carbon. Journal of Hazardous Materials, B135, 453-456 (2006)

10) Dastgheib, S.A., Karanfil, T. and Cheng, W.: Tailoring activated carbons for enhanced removal of natural organic matter from natural waters. Carbon, 42, 547-557 (2004)

11) Mangun, C.L., Benak, K.R., Economy, J. and Foster, K.L.: Surface chemistry, pore sizes and adsorption properties of activated carbon fibers and precursors treated with ammonia. Carbon, 39, 1809-1820 (2001)

12) Xia, W., Wang, Y., Bergsträßer, R., Kundu, S. and Muhler, M.: Surface characterization of oxygen-functionalized multi-walled carbon nanotubes by highresolution X-ray photoelectron spectroscopy and temperature-programmed desorption. Applied Surface Science, 254, 247-250 (2007)

13）近藤精一, 石川達雄, 安部郁夫：BET 理論による比 表面積の測定, pp38-42,「吸着の科学第 2 版」, 近 藤精一, 石川達雄, 安部郁夫, 丸善株式会社, 東京 (2001)

14) Katsura, M., Nishimaki, K., Nakagawa, T., Yamamoto, T.A., Hirota, M. and Miyake, M.: Thermodynamics of the formation of $\mathrm{CH}_{4}$ by the reaction of carbon materials by a stream of $\mathrm{NH}_{3}$. Journal of Nuclear Materials, 258-263, 839-842 (1998)

15）近藤精一, 石川達雄, 安部郁夫 : 活性炭の製造法, pp184-186, 「吸着の科学第 2 版」, 近藤精一, 石川 達雄, 安部郁夫, 丸善株式会社, 東京 (2001)

16) Chen, W., Cannon, F.S. and Rangel-Mendez, J.R.: Ammonia-tailoring of GAC to enhance perchlorate removal. I: Characterization of $\mathrm{NH}_{3}$ thermally tailored GACs. Carbon, 43, 573-580 (2005) 